\title{
Assessment of Heavy Metal Concentration in Ujjani Reservoir Water and Sediment, Maharashtra, India
}

\author{
Dnyaneshwar Shinde \\ Baburaoji Gholap College \\ Dnyanesh M. Mahajan \\ Baburaoji Gholap College \\ Sanjay D. Chakane ( $\nabla$ schakane@gmail.com )
}

\section{Research}

Keywords: Heavy Metals, Sediment, Acid Digestion, Ujjani Reservoir, Ecological Restoration

Posted Date: July 6th, 2020

DOI: https://doi.org/10.21203/rs.3.rs-38648/v1

License: () (i) This work is licensed under a Creative Commons Attribution 4.0 International License. Read Full License 


\section{Abstract}

The study was conducted to investigate heavy metal contents namely, Iron (Fe), Copper (Cu), Zinc (Zn), and Manganese (Mn) from surface sediment and water samples collected from the Ujjani Reservoir. The concentrations ( $\mathrm{mg} \mathrm{kg}^{-1}$ ) of Fe, $\mathrm{Cu}, \mathrm{Zn}$ and $\mathrm{Mn}$ in sediment detected were 4455.0, 184.05, 97.4, 1090.5 respectively, while in water metal contents $\left(\mathrm{mg} \mathrm{l}^{-1}\right) \mathrm{Fe}, \mathrm{Cu}, \mathrm{Zn}$, and $\mathrm{Mn}$ were $3.05,0.5,0.82$, and 2.56 correspondingly. The contents of metals in the studied samples showed a descending order such as $\mathrm{Fe}, \mathrm{Mn}, \mathrm{Zn}$ and $\mathrm{Cu}$. It was observed that the mean concentrations of $\mathrm{Fe}, \mathrm{Cu}$, and $\mathrm{Mn}$ were more in sediment and water, whereas, Zn contents were detected lesser than the standard levels proposed by USEPA 2004. The sediment pollution analysis was achieved using a Pollution load index (PLI), Geoaccumulation index $\left(I_{\text {geo }}\right)$ and Potential ecological risk index (RI). Similarly, risk of metals in water was evaluated using Average absorption dose (ADD), Hazardous quotient (HQ), and Hazardous index (HI). In our study, the ADD, HQ and HI values for metals were lower than 1 , indicating that there is no health risk associated with studied heavy metals present in surface water. Also sediment quality assessment shows that there is minor ecological risk of studied heavy metals. Even though, the Ujjani Reservoir has a lower ecological risk, its water and sediment quality is declining day by day. Therefore, there is a need to make a policy for ecological restoration to avoid further damage to the ecosystem and human beings.

\section{Introduction}

The soil and water is the extensive sink for the group of potentially lethal elements referred as heavy metals. It includes $\mathrm{Cd}, \mathrm{Pb}, \mathrm{Hg}, \mathrm{Cr}, \mathrm{Ni}, \mathrm{Mo} \mathrm{Zn}, \mathrm{Cu}, \mathrm{Mn}$, and Fe. These elements exhibit a range of properties in soil and water including the difference in mobility, bioavailability and leaching losses [1]. The uptake of these elements by plants is relatively small compared to the total quantities entering into the soil from different anthropogenic sources. This could have a long-term implication such as phytotoxicity at high concentrations, maintenance of soil, sediment microbial processes, and the transfer of zootoxic elements to the human diet through increased uptake by crops. Therefore, reducing heavy metal inputs into soil, sediments, and water is a strategic aim to protect the ecosystem [2]. Although excess accumulation of heavy metals has harmful effects, heavy metals in optimum quantity are important and necessary components of ecosystems and play a significant role in the daily biochemical activities of the living organism [3]. Among the heavy metals Fe, Cu, Mn, Ni and $\mathrm{Zn}$ are essential micronutrients for the body metabolism of living organisms when their concentrations are within the recommended thresholds. Though, other heavy metals like $\mathrm{Cd}, \mathrm{As}, \mathrm{Cr}, \mathrm{Pb}$ and $\mathrm{Hg}$ have not known for physiological role, therefore may create a serious health hazards even consumed at minimum concentrations $[4,5]$. Intake of heavy metals through contaminated food and water can lead to carcinogenic effects, including upper gastrointestinal cancer, decrease in immunological defenses and disabilities associated with malnutrition [6, 7].

The Ujjani Reservoir is the terminal Reservoir on the river Bhima, located in Solapur district of Maharashtra, India. The catchment area of the Reservoir, Upper Bhima Basin has extreme physiographic and agro-climatic variations. It is intensively urbanized and industrialized. The main river Bhima basin has a slope west to east from High Ridges of Ujjani's catchment. The River Bhima receives water from major tributaries namely Mula, Mutha, Indrayani, Ghod, Kukadi, Bhama, Pawana and Vel. A total of 14,500 sq. km of Ujjani's catchment lies in Pune District [8]. Bhima River carries and assimilates industrial waste and sewage generated by Pune and Pimpri Chinchwad area and finally pollutes the Ujjani Reservoir. Modern agricultural practices, including extensive use of chemical fertilizers and pesticides by farmers in water, irrigated agriculture area along the basin of reservoir are responsible for changing physicochemical properties of soil and water quality of the reservoir [9]. The human population surrounding the basin of the reservoir largely depends on the reservoir for drinking water, irrigation and fishery

Globally, the pollution of heavy metals in the aquatic environment is a serious issue and at present it has reached to an alarming state. Discharge of inorganic pollutants into water bodies and soil through different anthropogenic activities increases their level in natural environments which leads to biomagnifications in the food chain. It adversely affects soil ecology, ground and surface water quality, and ultimately harms the health of living organisms. Therefore, the detection of metal concentrations in the soil sediment becomes utmost important. As heavy metals cannot be degraded, they are being constantly deposited and incorporated in water, thus causing heavy metal pollution in freshwater bodies. The occurrence of heavy metals in the water may have an intense effect on the freshwater food chain. Furthermore, bioconcentration and magnification could lead to high toxicity in organisms. Apart from destabilizing the freshwater ecosystem, the accumulation of these toxic metals in the aquatic as well as terrestrial food web is hazardous to public health. Thus their possible long term impact on ecosystem integrity cannot be unnoticed [10]. Pollution of freshwater bodies especially the rivers is no longer within the safe limits for human consumption as well as for the life of aquatic fauna [11].

The lake sediments and water are the basic components of our environments as they provide key resources for the living organism. The surface run off transport metals to the stream, it can dissolve or corrode pollutants from soil and carry suspended sediments and adsorbed constituents to the stream [12]. Generally, Reservoir's bottom sediments and entire water are sensitive indicators to monitor contaminants in the aquatic environment [13]. Thus, the reservoir sediment and water analysis plays a vital role in evaluating the pollution status in the aquatic environment. Therefore, this study is targeted to monitor the contamination of some heavy metals such as $\mathrm{Fe}, \mathrm{Cu}, \mathrm{Zn}, \mathrm{Mn}$ in soil sediments and surface water of Ujjani Reservoir. The heavy metals have been selected as per their common environmental concern along with health hazards to the human beings, animals as well as to the aquatic life.

\section{Materials And Methods}

\subsection{Study Site and Sample Collection}

The surface water and sediment samples were collected from the Ujjani reservoir. The Ujjani reservoir (Topo sheet No. 47 N/4; Latitude 180 04' 24" N and Longitude 750 07' 15" E) is located in the district Solapur (Taluka-Madha). Its catchment area is about 14856 Sq. km. This reservoir obtains water by several rivers such as Mula, mutha and Bhima. The river Bhima originate from Bhimashankar hills situated in western hills of Maharashtra. Later, these rivers pass through metropolitan and industrialized cities named as Pune, Pimpri Chinchwad and Chakan. Finally, the river water is cached in Ujjani reservoir. Here, we

Loading [MathJax]/jax/output/CommonHTML/jax.js nent area of Ujjani Reservoir. The surface water and sediment samples were collected during May 2019 to Jule 
2019; the sediment samples were collected up to $15 \mathrm{~cm}$ depth from various sampling points and kept separately in clean polythene bags. Similarly, surface water samples were collected from the same sampling stations during Pre-Monsoon season. All samples were collected and brought to the laboratory and processed further for analysis of heavy metals such as Fe, Cu, Zn and Mn using Atomic Absorption Spectroscopy.

\subsection{Preparation of Sediment sample}

The surface sediment samples were collected from each sampling points were dried in a hot air oven at $105^{\circ} \mathrm{C}$ for 6 hours and then grinded in a mortar and pestle. All samples were sieved through a $0.2 \mathrm{~mm}$ plastic mesh and processed further. The surface sediment samples from each sampling points were weighed $1 \mathrm{~g}$ and digested with a mixture of concentrated $\mathrm{HNO}_{3}$ and $\mathrm{HClO}_{4}(3: 1)$ initially at $40^{\circ} \mathrm{C}$ for 1 hour, followed by $140-160^{\circ} \mathrm{C}$ for 2 hours on a hot plate. Afterward, digested samples were diluted with $50 \mathrm{ml}$ of double-distilled water and subsequently filtered through a Watman filter paper (45Micron). The concentrations of the elements are determined using AAS (AAS Model, Sistronic- 203).

\subsection{Preparation of Water Sample}

In order to determine the metal contents in surface water of Ujjani Reservoir, we have collected samples from different stations, each of 1 liter at every sampling station. Initially samples were treated with concentrated $\mathrm{HNO}_{3}(3 \mathrm{ml})$. Later, $50 \mathrm{ml}$ of sample from each sampling point was evaporated separately for 30 minutes on a hot plate. Next, samples were digested in a concentrated $\mathrm{HNO}_{3}$ at $140^{\circ} \mathrm{C}$ for 1 hour on a hot plate. Thereafter digested samples were diluted using double distilled water and filtered through Watman filter paper. All samples were stored at $4{ }^{\circ} \mathrm{C}$ for further analysis. The concentrations of each element were quantified using an atomic absorption spectrophotometer (AAS Model, Sistronic 203).

\subsection{Statistical Analysis}

A total of 12 surface sediment samples were collected in triplicate from different sampling stations and analyzed to determine the level of different metals such as Fe, Cu, Zn and Mn. Similarly, surface water samples were collected from different sampling points. The obtained values were subjected for analysis of mean, standard deviation and standard errors.

\subsection{Risk assessment on human health}

\subsubsection{Average Daily Dose of metals (ADD)}

The exposure of humans to metal occurs mainly through direct ingestion with drinking water [14]. The metal dose received via ingestion pathway was calculated using following formula [14]

$$
\mathrm{ADD}=\frac{(\mathrm{Cx} \times \mathrm{IR} \times \mathrm{EF} \times \mathrm{ED})}{\mathrm{BW} \times \mathrm{AT}}
$$

1

Where ADD is an average daily dose, $\left(\mathrm{mg} \mathrm{kg}^{-1}\right.$ day $\left.^{-1}\right) C x$ is the average concentration of metals in water( $\left(\mathrm{mg} \mathrm{I}^{-1}\right.$ day $\left.^{-1}\right), \mathrm{IR}$ is the ingestion rate, $\left(2 \mathrm{~L} \mathrm{day}^{-1}\right)$, BW is an average body weight of Indian male $(57 \mathrm{~kg})$ and female (50 kg) [15]. EF is the exposure frequency (365 days year $\left.{ }^{-1}\right)$. ED is the exposure duration (67 years) (life expectancy of Indian male $=65$ years approximately and for Indian females is 68) years approximately. Therefore, an average of two extremes has been considered. AT is the averaging time for non-carcinogens (365 days year ${ }^{-1} \times$ ED) [16].

\subsubsection{Hazard Quotient (HQ)}

The risk characterization of heavy metals was detected by potential noncarcinogenic risks, the hazard quotient (HQ), which was determined by following equation.

$$
\mathrm{HQ}=\frac{\mathrm{ADDing}}{\mathrm{RfD}}
$$

2

$\mathrm{HQ}$ is the hazard quotient of an individual metal, where RfD originates from risk-based concentration table [17]. The values of RfD for Cu, Zn and Mn are-, 5, 1, 1 respectively.

\subsubsection{Hazard Index (HI)}

For determining the risk assessment of multiple metals in the drinking water, a hazard index $(\mathrm{HI})$ was employed by summing all the calculated $\mathrm{HQ}$ values of metals. The value of $\mathrm{HI}>1$ indicated a potential for an adverse effect on human health [14]. To assess the overall potential for non-carcinogenic effects posed by more than one chemical, a HI approach has been developed based on EPA's [18].

$$
\mathrm{HI}=\mathrm{THQFe}+\mathrm{THQCu}+\mathrm{THQZn}+\mathrm{THQMn}
$$

3

\subsection{Ecological risk assessment of heavy metals in sediment}

\subsubsection{Pollution load index (PLI)}


Pollution load index (PLI) represents the number of times by which the metal content in the sediment exceeds the background concentration [19]. If the value of PLI is $>1$ it indicates polluted, whereas $<1$ specifies no pollution [20]. PLI was assessed using the following formula offered by Tomilson et al. (1980) [21]. Where $\mathrm{n}$ is the number of metals (four in the present study) and CF is the contamination factor. The contamination factor and pollution load index can be determined from the following relation:

$$
P I L=(C F 1 \times C F 2 \times C F 3 \ldots \times C F n)^{\frac{1}{n}}
$$

4

$\mathrm{CF}=$ Metal concentration in sediment / Background value of metal

According to Hankinson (1980) [22], CF $<1$ indicates low degree of contamination, $1<\mathrm{CF}<3$ indicates moderate degree of contamination, $3<\mathrm{CF}<6$ indicates considerable degree of contamination, and CF $>6$ indicates very high degree of contamination.

\subsubsection{Geoaccumulation index (/geo)}

The Geoaccumulation index ( $\left.I_{\text {geo }}\right)$ is used to calculate metals contamination in sediments, by comparing current concentrations with pre-industrial or precontamination levels [23]. $I_{\text {geo }}$ is mathematically expressed as:

$$
\mathrm{I}_{\text {geo }}=\frac{\log _{2} \times \mathrm{Cx}}{1.5 \times \mathrm{B}}
$$

5

Where $C x$ is the concentration of element and $B$ is the geochemical background value of metal. The background values for Fe $46700, C u 28, \mathrm{Zn} 95$, and $\mathrm{Mn}$ 850. The World surface rock average was used as background values [24]. The factor 1.5 is merged in the relationship to account for potential variation in background data due to lithogenic effect [25].

\subsubsection{Potential ecological risk index (RI)}

The determination of the probable ecological risk index of the heavy metal contamination is a diagnostic tool to assess the water pollution. As a result of the growing content of heavy metals in sediments and their subsequent release into the water, could threaten ecological health [26]. According to this method, the possible ecological risk coefficient ER of a single element and the potential ecological risk index RI of the multi element can be computed via the following equations:

$$
\mathrm{ER}=\mathrm{TR} \times \mathrm{CF}
$$

6

and $R I=\sum_{i=n}^{n}(\mathrm{ER})(7)$

Where $\mathrm{CF}$ is the pollution coefficient of a single element. TR is the toxic response factor for the specified element of which accounts for the toxic requirement and the sensitivity requirement. The toxic response factors for $\mathrm{Cu}, \mathrm{Zn}$ and $\mathrm{Mn}$ were 5,1 , and 1, respectively [27]. The average shale background concentration of global sediments is selected as the reference baselines in this study.

\section{Results}

Ujjani Reservoir is the third largest dam in Maharashtra state with capacity of 117 TMC and it reservoir receives water mainly from highly polluted metropolitan cities such as Pune and Pimpri Chinchwad. This prompted us to investigate heavy metal accumulation in sediment and surface water of Ujjani Reservoir. Here, we have determined the concentrations of various heavy metals in surface sediment and surface water samples collected from different sampling stations of the Ujjani Reservoir using an Atomic Absorption Spectrophotometer (AAS). Furthermore, we have determined the risk levels of metals in reservoir water by different standards such as daily absorption dose (ADD), hazardous quotient (HQ) and hazardous index (HI). The ecological risk for sediment was evaluated using pollution load index (PLI), Geoaccumulation $\left(I_{\text {geo }}\right)$ and potential ecological risk (ER and RI) for different studied metals. The all determined concentrations of different heavy metals are shown in Table 1 and Table 3. 
Table 1

Heavy metal concentrations ( $\mathrm{mg} \mathrm{kg}^{-1}$, dry weight) in sediments of the Ujjani reservoir. Values are Mean \pm S.E.

\begin{tabular}{|llllll|}
\hline Sampling Stations & $\begin{array}{l}\text { Sampling } \\
\text { Points }\end{array}$ & Fe & Cu & Zn & Mn \\
\hline Kalthan No.1 & URL1 & $4455 \pm 30$ & $105.2 \pm 0.6$ & $58.9 \pm 0.3$ & $545 \pm 4.8$ \\
\cline { 2 - 6 } & URL2 & $4441.5 \pm 41.5$ & $184.05 \pm 3.85$ & $75.36 \pm 0.34$ & $764.4 \pm 0.4$ \\
\cline { 2 - 6 } & URL3 & $3205.5 \pm 0.50$ & $106.7 \pm 0.4$ & $65.25 \pm 0.25$ & $657 \pm 11$ \\
\hline Padashtal & URL4 & $3587.85 \pm 12.35$ & $99.7 \pm 1.5$ & $64.5 \pm 0.7$ & $797.35 \pm 1.35$ \\
& URL5 & $1820.15 \pm 184.85$ & $67.22 \pm 3.02$ & $48.8 \pm 3.4$ & $674.9 \pm 6.6$ \\
\cline { 2 - 6 } & URL6 & $3737.75 \pm 14.25$ & $142.64 \pm 1.94$ & $69.95 \pm 0.05$ & $480.45 \pm 4.25$ \\
\hline Bhimanagar & URL7 & $3903.4 \pm 2.4$ & $111.75 \pm 2.05$ & $65.8 \pm 2.2$ & $840.25 \pm 31.75$ \\
\cline { 2 - 6 } & URL8 & $4352.1 \pm 32.9$ & $103.66 \pm 1.66$ & $64.92 \pm 0.67$ & $1090.5 \pm 18.95$ \\
\cline { 2 - 6 } & URL9 & $4319.15 \pm 113.95$ & $179.11 \pm 3.65$ & $97.4 \pm 1.1$ & $419.11 \pm 3.51$ \\
\cline { 2 - 6 } & URL10 & $954.4 \pm 18.7$ & $94.05 \pm 2.15$ & $41.3 \pm 7.4$ & $797.03 \pm 2.47$ \\
\cline { 2 - 6 } & URL11 & $4234.75 \pm 67.35$ & $103.8 \pm 3.2$ & $63.3 \pm 0.3$ & $725.9 \pm 3$ \\
\cline { 2 - 6 } & URL12 & $4355 \pm 30$ & $122.05 \pm 10.05$ & $63.22 \pm 1.01$ & $638.94 \pm 6.255$ \\
\hline
\end{tabular}

\subsection{Heavy metal contents in sediment surface}

In this study, we have determined the concentrations of various heavy metals in sediment samples collected from Ujjani Reservoir. The mean concentration of Fe in the sediment was observed in a range between 954.4 to $4455 \mathrm{mg} \mathrm{kg}^{-1}$ (see Table 1, Fig. 1A). The lowest mean concentration of Fe was observed at Bhimanagar in sampling point URL10, while the highest concentration was detected at Kalthan No. 1 in sampling point URL1. Next, the concentration of Cu in surface sediment was observed in between 67.022 to184.05 $\mathrm{mg} \mathrm{kg}^{-1}$ (Table 1, Fig. 1B). The highest Cu content was detected at station Kalthan No.1 and in sampling point URL 2; however minimum Cu content was found at station Padashtal in sampling URL 5. Later on, we have determined the concentration of Zn in surface sediment, which was observed highest at Bhimanagar station in sampling point URL $9\left(97.4 \mathrm{mg} \mathrm{kg}^{-1}\right)$, the minimal Zn (41.3 mg kg-1) concentration was also observed at Bhimanagar in sampling point URL 10 ( See Table 1, Fig. 1C). At the end, we quantified Mn concentration, which was maximum in sediment at Padashtal in sampling point URL 8, whereas the least Mn concentration was at Bhimanagar in sampling point URL 9. (See Table 1 and Fig. 1D). All values observed in the sediment samples were above the normal range except for the $\mathrm{Zn}$. The content of $\mathrm{Zn}$ in surface sediment was below the normal value proposed by various environmental protection agencies (see Table 3).

\subsection{Ecological risk assessment of sediment}

In the present study, ecological risk assessment of heavy metals in sediment was analyzed by considering numerous parameters for example pollution load index, geoaccumulation index and potential ecological risk. Pollution load index values for different heavy metals in the sediments were ranged between $0.60-0.63$ in all studied stations (Table 2). PLIs for the heavy metals in the sediments were less than 1 in all stations. The results of the calculated /geo showed that stations had values less than 1 for Fe, $\mathrm{Cu}, \mathrm{Zn}$, and $\mathrm{Mn}$ (Table 2). The individual potential risks (ER) of studied heavy metals and their aides to the potential ecological risk index (RI) exhibited that $\mathrm{Cu}$ had the highest ER in all the three stations. Whereas, other heavy metals were much lower ER than standards. The ER values of studied metals in the sediments have showed the order such as: $\mathrm{Cu}>\mathrm{Mn}>\mathrm{Zn}$. The values of RI decreased in the order of: station 3 > station 1 > station 2. The potential ecological risk index (RI) values for stations 1, 3, and 2 were 23.6, 24.14, and 20.5, respectively (Table 2).

Table 2

The contamination level and potential ecological risk of toxic elements in bottom sediments of Ujjani reservoir. $\left(I_{\text {geo }}{ }^{-}\right.$

Geoaccumulation index, PLI- pollution load index, RI- ecological risk, ER-individual ecological risk)

\begin{tabular}{|lllllll|}
\hline Sampling Site & \multicolumn{1}{l}{$I_{\text {geo }}$} & & \multicolumn{5}{c|}{ PLI } & RI \\
& Fe & Cu & Zn & Mn & & \\
\hline Kalthan No1 & -4.15 & 1.56 & -1.11 & -0.88 & 0.66 & 23.6 \\
\hline Padashtal & -4.34 & 1.33 & -1.19 & -0.72 & 0.63 & 20.5 \\
\hline Bhimanagar & -4.33 & 1.57 & -1.1 & -0.98 & 0.60 & 24.14 \\
\hline ER & & 21.1 & 0.65 & 0.79 & & \\
\hline
\end{tabular}

\section{Description}


Concentrations of $\mathrm{Fe}(\mathrm{A}), \mathrm{Cu}(\mathrm{B}), \mathrm{Zn}(\mathrm{C})$ and $\mathrm{Mn}(\mathrm{D})$ at various sampling points. Mean and standard errors are compared (Mean $\pm \mathrm{SE})$. Concentration in (mg $\mathrm{kg}^{-1}$ dry weight).URL- Ujjani reservoir location (Sampling Points), $\mathrm{n}=3$.

\subsection{Heavy metal contents in surface water:}

The surface water samples in Ujjani Reservoir were collected from three different stations and various metal (Fe, Cu, Zn and Mn) contents were quantified using AAS. The risk level of metals was estimated by average daily dose (ADD), hazardous quotient (HQ) and hazardous index (HI) of heavy metals in water were calculated for Indian male and female. (Table 4) The mean concentration of Fe was in a range between 2.14 to 3.05 mg I-1 (see Table 3, Fig. $2 \mathrm{~A}$ ). The Fe concentration in surface water was detected highest at Padashtal in sampling point L2.The concentration values of Fe, Cu, Zn and Mn detected in surface water were above the normal range. Moreover, we also found that the concentration of $\mathrm{Cu}$ in surface water ranged between 0.50 to $0.135 \mathrm{mg} \mathrm{I-1}$. It was observed that the minimum Cu concentration at Kalthan No. 1 in sampling point L1 and maximum at Padashtal in sampling point L2 (see Table 3, Fig. 2B). The range of $\mathrm{Zn}$ in surface water was in between 0.82 to $0.62 \mathrm{mg} \mathrm{I}^{-1}$ (see Table 3, Fig. $2 \mathrm{C}$ ). In surface water, it exceeds the regulatory standards. The surface water content of $\mathrm{Mn}$ at Padashtal in sampling point L2 was $2.56 \mathrm{mg} \mathrm{I}^{-1}$ which was more than $2.125 \mathrm{mg} \mathrm{I}^{-1}$ found at Bhimanagar in sampling point, L3 (see Table 3, Fig. 2D). Concentrations of Fe, $\mathrm{Cu}, \mathrm{Mn}$, and $\mathrm{Zn}$ in both surface sediment and surface water showed in a descending order such as Fe, $\mathrm{Mn}$, $\mathrm{Zn}$ and $\mathrm{Cu}$. Similar results were also noticed by Fang et al. 2009.

Table 3

Heavy metal concentrations ( $\mathrm{mg} \mathrm{l}^{-1}$ ) in the surface water of Ujjani Reservoir at various sampling stations. (Mean \pm standard Errors).

\begin{tabular}{|llllll|}
\hline Sampling Stations & $\begin{array}{l}\text { Sampling } \\
\text { Points }\end{array}$ & $\mathrm{Fe}$ & $\mathrm{Cu}$ & $\mathrm{Zn}$ & $\mathrm{Mn}$ \\
\hline Kalthan No. -2 & $\mathrm{~L} 1$ & $2.4 \pm 0.2$ & $0.135 \pm 0.025$ & $0.82 \pm 0.18$ & $2.125 \pm 0.775$ \\
\hline Padashtal & L2 & $3.05 \pm 0.35$ & $0.50 \pm 0.08$ & $0.62 \pm 0.06$ & $2.56 \pm 0.46$ \\
\hline Bhimanagar & L3 & $2.14 \pm 0.06$ & $0.215 \pm 0.005$ & $0.705 \pm 0.015$ & $2.14 \pm 0.5$ \\
\hline
\end{tabular}

\section{Description}

Concentrations of $A(F e), B(C u), C(Z n)$ and $D(M n)$ in surface water sample collected from different locations. L1. L2, L3. Mean and standard errors are compared (Mean $\pm \mathrm{SE})$ concentration in $\left(\mathrm{mg} \mathrm{l}^{-1}\right)$. $(\mathrm{n}=3)$

\subsection{Human health risk assessment of heavy metals (ADD, HQ and $\mathrm{HI}$ )}

The ADD values through consumption of water were observed higher in female than male. It shows the metal order as: Fe $>M n>C u>Z n$, respectively, in all studied location (Table 4). The HQ values for metals Fe, Cu, Zn and $\mathrm{Mn}$ in all stations along the reservoir were lower than 1.0 (Table 4). However, the computed hazard index (HI) values for location such as Kalthan No1, Padashtal and Bhimanagar was observed $0.37,0.74$ and 0.41 respectively. These results suggest that there is no cumulative potential of adverse health risk via direct ingestion exposure.

Table 4

Health Risk Assessment for Metals in surface Water Samples from Ujjani reservoir through Ingestion. M- Male, F- Female, (ADD- average daily dose, HQ- haza $\mathrm{HI}$ - hazardous index)

\begin{tabular}{|c|c|c|c|c|c|c|c|c|c|c|c|c|c|c|c|c|}
\hline \multirow{3}{*}{$\begin{array}{l}\text { Sampling } \\
\text { station }\end{array}$} & \multicolumn{4}{|l|}{$\mathrm{Fe}$} & \multicolumn{4}{|l|}{$\mathrm{Cu}$} & \multicolumn{4}{|l|}{$\mathrm{Zn}$} & \multicolumn{4}{|l|}{ Mn } \\
\hline & \multicolumn{2}{|l|}{$A D D$} & \multicolumn{2}{|l|}{ HQ } & \multicolumn{2}{|l|}{$A D D$} & \multicolumn{2}{|l|}{$\mathrm{HQ}$} & \multicolumn{2}{|l|}{ ADD } & \multicolumn{2}{|l|}{$\mathrm{HQ}$} & \multicolumn{2}{|l|}{ ADD } & \multicolumn{2}{|l|}{ HQ } \\
\hline & $M$ & $\mathbf{F}$ & $M$ & $\mathbf{F}$ & $M$ & 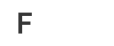 & $M$ & $\mathbf{F}$ & $M$ & $\mathbf{F}$ & $M$ & $F$ & $M$ & $\mathbf{F}$ & M & $\mathbf{F}$ \\
\hline $\begin{array}{l}\text { Kalthan } \\
\text { No.1 }\end{array}$ & 0.081 & 0.093 & 0.11 & 0.13 & 0.0045 & 0.0052 & 0.12 & 0.14 & 0.027 & 0.031 & 0.09 & 0.10 & 0.072 & 0.082 & 0.0072 & 0.0082 \\
\hline Padasthal & 0.10 & 0.11 & 0.14 & 0.15 & 0.017 & 0.019 & 0.45 & 0.51 & 0.021 & 0.024 & 0.07 & 0.08 & 0.087 & 0.099 & 0.0087 & 0.0099 \\
\hline Bhimanagar & 0.072 & 0.083 & 0.10 & 0.11 & 0.0071 & 0.0081 & 0.19 & 0.21 & 0.023 & 0.027 & 0.07 & 0.09 & 0.072 & 0.083 & 0.0072 & 0.0083 \\
\hline
\end{tabular}

\section{Discussion}

Generally, microelements are beneficial to plants and human beings in adequate quantity, but its more abundance in freshwater bodies causes deleterious effects [28]. The reservoirs are the main source of water, which is used on a large scale for drinking, livestock and irrigation purpose. Industrialization, Urbanization and agricultural practices release a huge amount of wastewater in the river Bhima and its tributaries are getting adversely affected. This results in pollution of water and its bottom sediment. Reservoir water is widely used for drinking and irrigation purpose and due to its contamination; affects quality of soil in the agricultural land. The long term continues irrigation of crops with higher concentrations of a pollutant than the standards proposed by the environmental agency may lead to bio-magnifications at various tropic levels in the food chain. The polluted water interrupts soil fertility and productivity [29]. 
Table 5

Guidelines for concentrations of heavy metals in river sediments $\left(\mathrm{mg} \mathrm{kg}^{-1}\right)$ and surface water( $\left.\mathrm{mg} \mathrm{I}^{-1}\right)$. ( *long-term trigger value (LTV) and short-term trigger value (STV) designed for agriculture irrigation water standards).

\begin{tabular}{|llllllll|}
\hline Sr. No & Sample & Guidelines & Fe & Cu & Mn & Zn & References \\
\hline 1 & Sediment & USEPA 2004 & 30 & 16 & 30 & 120 & {$[30,31]$} \\
\hline 2 & Surface Water & USEPA 2004 & 0.3 & 0.0025 & 0.05 & 0.005 & {$[32]$} \\
\hline 3 & Irrigation Water & ANZECC (LTV) & 0.2 & 0.2 & 2 & 0.2 & {$[33]$} \\
4 & Irrigation Water & ANZECC & 10 & 5 & 5 & 10 & {$[33]$} \\
& & & & & & & \\
\hline
\end{tabular}

The level of $\mathrm{Zn}$ in natural surface waters is normally below $10 \mathrm{mg} \mathrm{l}^{-1}$. Long-term exposure of $\mathrm{Zn}$ to various mammalian species causes tissue toxicity. Excessive $\mathrm{Zn}$ intake leads to Cu deficiency in humans [34] The Zn level of about $0.005 \mathrm{mg} \mathrm{I}^{-1}$ in drinking water is optimum for human health. Our results revealed that $\mathrm{Zn}$ contents were more abundant in water samples than standard recommended values (Ministry of the Environment, 2004) [30] (see Table 5). However, the concentration of Zn in surface sediment was below the standards recommended by USEPA 2004[30]. Zinc is one of the important trace elements, plays a vital role in the physiological and metabolic processes of living organisms. However, its higher concentrations can be toxic to the organism. An elevated level of $\mathrm{Zn}$ in the diet has been shown to induce hypocalcaemia and bone desorption in rats [35]. Apart from this, carcinogenicity studies on mammals showed that zinc- ethanoate in drinking water (about $1.5 \mathrm{mg} \mathrm{l}^{-1}$ ) induce the metastases and sarcoma [36].

The $\mathrm{Mn}$ in surface water is usually related to industrial pollution. On the basis of the provisional health-based guidelines, the standard value for Mn in drinking water is $0.5 \mathrm{mg} \mathrm{l}^{-1}$. Here, we found that the values of $\mathrm{Mn}$ detected in surface water and sediment were higher than the permissible limit recommended by USEPA 2004[30]. The Mn concentration more than $30 \mathrm{mg} \mathrm{kg}^{-1}$ in sediment causes hazardous effect to the ecosystem. The higher dose of Mn through the drinking water is associated with cancer risk. Several researchers have discovered that in different living organisms such as Drosophila melanogaster and mice the excess application of Mn enhances the frequency of mutations, chromosomal aberrations, tumor incidences, pancreatic cancer and pituitary adenomas [37]. Moreover, our results revealed that $\mathrm{Fe}, \mathrm{Cu}, \mathrm{Mn}$ and $\mathrm{Zn}$ concentrations in surface water were in excess in comparison with standards set for irrigation water by the ANZCC 2000[33]. Hence, continues land irrigations with water may affect soil profile of area around the Ujjani Reservoir.

Human health risk assessment of heavy metals in water specifies that the ADD through consumption of water was below the unit in all stations. As per the] risk assessment indices, If the value of the hazard quotient (HQ) is greater than 1.0, it indicates a high probability of adverse health effects due to exposure [14] In addition, the hazard quotients were lower than the postulated guidelines, suggesting that communities exposed to this water through ingestion pathways are at no risk of sickness associated with consumption of high levels of these contaminants. Also the mean $\mathrm{HI}$ of the examined stations was lower than unit, indicating there was no cumulative potential for adverse health risk with regard to reservoir water.

The Pollution load index (PLI) provides comprehensive information about the metal toxicity in a particular sample [19]. The PLI value of $>1$ specifies polluted, whereas $<1$ designates no pollution [20]. In our study, PLIs for the heavy metals in the studied sediments were less than 1 in all stations. The geoaccumulation index (/geo) is used to quantify the contamination of metals in sediments, by comparing current concentrations of metals with the pre-industrial levels. Muller classification of Igeo, grouped it into seven grades: Igeo $\leq 0$ (grade 0 ), unpolluted; $0<\leq 1$ (grade 1), slightly polluted; $1<$ ggeo $\leq 2$ (grade 2 ), moderately polluted; $2<$ lgeo $\leq 3$ (grade 3), moderately severely polluted; $3<$ lgeo $\leq 4$ (grade 4), severely polluted; $4<$ lgeo $\leq 5$ (grade 5 ), severely to extremely polluted; and Igeo $>5$ (grade 6), extremely polluted [23]. Here, the values of /geo of studied metals were lower than $0 \mathrm{for} F e, \mathrm{Mn}$ and $\mathrm{Zn}$ whereas values of $/ g e o$ for $\mathrm{Cu}$ are between 1 and 2 indicating sediments are moderately polluted with $\mathrm{Cu}$ and there is lower risk to ecosystem of the reservoir.

The valuation of the possible risk of the heavy metal contamination was proposed by Swedish scholar Hokinson. It is a method to estimate the heavy metal contamination from the viewpoint of sedimentology. According to this method, the potential ecological risk(ER) coefficient are computed for single element and potential ecological risk index (RI) for the multielement. According to Hakanson the following terminologies are suggested for the ER and RI values: (1) ER $<40$, low ecological risk; $40<E R \leq 80$, moderate ecological risk; $80<E R \leq 160$, appreciable ecological risk; $160<E R \leq 320$, high ecological risk; and > 320, serious ecological risk; Also, $\mathrm{RI}<150$, low ecological risk; $150<\mathrm{RI}<300$, moderate ecological risk; $300<\mathrm{RI}<600$, high ecological risk; and $\mathrm{RI} \geq 600$, significantly high ecological risk.[22]. RI method contains biological toxicology, environmental chemistry and ecology. It can assess ecological risks caused by heavy metals systematically [22]. In the present study, values of ER and RI were less than 40and 150 respectively, indicating that Ujjani reservoir have lower ecological risk for all studied metals.

\section{Conclusions}

Here, the study conducted on the analysis of heavy metal contents in surface sediments of the Ujjani Reservoir revealed that the concentrations of Fe, Cu and $\mathrm{Mn}$ were above the critical limit as per standard guidelines proposed by the Ministry of environment USEPA 2004[30]. Similarly, the mean concentration of Fe, $\mathrm{Cu}, \mathrm{Zn}$ and $\mathrm{Mn}$ in surface water were found to be higher than the normal level. In our study, the ADD, HQ and HI values for metals were indicating that there is no health risk associated with studied heavy metals present in surface water for human health. Also sediment quality assessment such as PLI, Igeo, ER and RI values shows that there is minor ecological risk of studied heavy metals. Heavy metal contamination creates an adverse effect on the ecosystem of the Reservoir. A higher concentration of heavy metals in freshwater habitat affects the benthic living organism and causes biomagnifications at the higher tropic level. The concentrations of studied metal clearly indicate that the reservoir environment is greatly deviating from standards proposed by USEPA 2004[30]

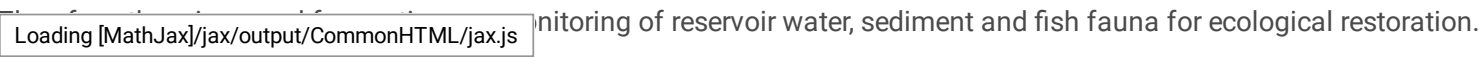




\section{Declarations}

\section{Availability of data and materials}

All data generated or analyzed during this study are included in this published article (and its supplementary information files).

\section{Competing interests}

The authors declared that they have no conflicts of interest in this work. We do not have any commercial or associative interest that represents a conflict of interest in connection with the work submitted.

\section{Funding}

NA

\section{Authors' contributions}

Dnyaneshwar Shinde and Sanjay Chakane designed the study, performed experimentation, analyzed and interpreted data and drafted manuscript, D.M. Mahajan and Sanjay Chakane finalized manuscript.

\section{Acknowledgements}

The authors wish to acknowledge ITSPM'S, Arts Science and Commerce College, Indapur for making available instrumentation facilities. Also, we wish to acknowledge Dr. Pramod Kambale (Department of Environmental Science, Savitribai Phule Pune University) and Dr. J.P. Sarwade (Department of Zoology, A.S.C. College Indapur) for providing laboratory facilities.

\section{References}

1. Nnorom IC, Ewuzie U. Comparative study of trace metal ( $\mathrm{Cd}, \mathrm{Cr}, \mathrm{Cu}, \mathrm{Fe}, \mathrm{K}, \mathrm{Mg}, \mathrm{Na}$, and $\mathrm{Zn}$ ) contents of local and imported vegetable oil brands consumed in Nigeria. J. of Plant Sci and Res. 2015;5:22-29.

2. Nicholson FA, Smith SR, Alloway BJ, Carlton-Smith C, Chambers BJ. An inventory of heavy metals inputs to agricultural soils in England and Wales. Sci of the Tot Envi. 2003;311:205-19.

3. Singh R, Gautam N, Mishra A, Gupta R. Heavy metals and living systems: An overview. Indi J of Pharmaco. 2011;43: 246-53.

4. Cohen T, Hee SSQ, Ambrose RF. Trace metals in fish and invertebrates of three California Coastal Wetlands. Marine Poll 2001;42:224-32.

5. Bruins MR, Kapil S, Oehme FW. Microbial resistance to metals in the environment. Ecotoxi and Envi 2000;45:198-207.

6. lyengar GV, Nair PP. Global outlook on nutrition and the environment: Meeting the challenges of the next millennium. Sci of the Tot Envi. 2000;249: 33146.

7. Jan FA, Ishaq M, Khan S, Ihsanullah I, Ahmad I, Shakirullah M. A comparative study of human health risks via consumption of food crops grown on wastewater irrigated soil (Peshawar) and relatively clean water irrigated soil (lower Dir). J of Hazar 2015;179: 612-21.

8. MS Kodarkar, Vidyanand Ranade, Sandeep Joshi, AR. Supate, Viswas Yeole and Shanti Vaidya. Integrated lake basin management (ilbm) - a case study of Yeshwantsagar (ujjani), Maharashtra, India. Upper Bhima Basin (UBB) and Ujjani reservoir.2007;1 - 13.

9. Dnyaneshwar Shinde, Dnyanesh Mahajan, Madhuri Kale, Ashvini Pawar, Sanjay Chakane. Trace Metal Accumulation in Water, Soil and Crop Plants along the Basin of Ujjani Reservoir, India. Adv in zool and Bot. 2020;8(in Press).

10. Ogoyi CJ, Mwita EK, Nguu PM, Shiundu. Determination of heavy metal content in water, sediment and microalgae from lake Victoria, East Africa. Open Envir Engin J.2011;4;156-61.

11. Nazir R, Khan M, Masab M, Rehman HU, Rauf NU, Shahab S, Ameer N, Sajed M, Ullah M, Rafeeq M, Shaheen Z. Accumulation of heavy metals (Ni, Cu, Cd, $\mathrm{Cr}, \mathrm{Pb}, \mathrm{Zn}, \mathrm{Fe}$ ) in the soil, water and plants and analysis of physico-chemical parameters of soil and water collected from Tanda Dam Kohat. J of Pharma Sci Res.2015;7:89-97.

12. Pak G, Jung M, Kim H, Mallari KJB, Chung G, Kim S, Kim Y, Oa S, Yoon J. Bewertung von Metalllasten in einem sauerwassergeprägten Einzugsgebiet. Mine. Wat and Envi J. 2016;35:44-54.

13. Suresh G, Sutharsan P, Ramasamy V, Venkatachalapathy R. Assessment of spatial distribution and potential ecological risk of the heavy metals in relation to granulometric contents of Veeranam lake sediments, India. Ecotoxi and Envi Safty. 212;84:117-24.

14. USEPA (US Environmental Protection Agency). (2004). Risk Assessment Guidance for Superfund Volume I: Human Health Evaluation Manual (Part E, Supplemental Guidance for Dermal Risk Assessment) Final. EPA/540/R/99/005 OSWER 9285.7-02EP PB99-963312 July 2004, Office of Superfund Remediation and Technology Innovation, Washington, DC.

15. Shukla HC, Gupta PC, Mehta HC, Hebert JR. Descriptive epidemiology of body mass index of an urban adult population in western India. J of Epidemio and Commu Health. 2002;56:876-80.

16. USEPA (United States Environmental Protection Agency) (2011) USEPA Regional Screening Level (RSL) Summary Table: November 2011.

17. USEPA (US Environmental Protection Agency). (1993). Carcinogenicity assessment. Washington: IRIS (Integrated Risk Information System), 2003.

18. USEPA (US Environmental Protection Agency). (1986). Guidelines for the health risk assessment of chemical mixtures. 51 Federal Register 34014

Loading [MathJax]/jax/output/CommonHTML/jax.js 
19. Yang Z Lu W, Long Y, Bao X, Yang Q. Assessment of heavy metals contamination in urban topsoil from Changchun City, China. J of Geochem Explo. 2011;108:27-38.

20. Barakat A, El Baghdadi M, Rais J, Nadem S. Assessment of heavy metal in surface sediments of day river at Beni-Mellal-Region, Morocco. Res J of Envi and Ear Sci. 2002;4:797-806.

21. Tomilson DC, Wilson JG, Harris CR, Jeffrey DW. Problems in assessment of heavy metals in estuaries and the formation of pollution index. Helgol Meeresunlters. 1980;33:566-75.

22. Hakanson L. An ecological risk index for aquatic pollution control - a sedimentlogical approach. Wat Res. 1980;14:975-1001.

23. Muller G. Index of geoaccumulation in sediments of the Rhine River. Geolol J. 1969;2:109-18.

24. Tang W, Zhang C, Zhao Y, Shan B, Song Z. Pollution, toxicity, and ecological risk of heavy metals in surface river sediments of a large basin undergoing rapid economic development. Envi Toxico and Chem.2016; 36:1149-55.

25. Wang J, Du H, Xu Y, Chen K, Liang J, Ke H, Cheng S, Liu M, Deng H, He T, Wang W, Cai M. Environmental and Ecological Risk Assessment of trace metal contamination in mangrove ecosystems: a case from Zhangjiangkou Mangrove National Nature Reserve, China. BioMed Res Inte. 2016;2016:1-14.

26. Rahman MS, Saha N, Molla AH. Potential ecological risk assessment of heavy metal contamination in sediment and water body around Dhaka export processing zone, Bangladesh. Envi Earth Sci.2013;71:293-308.

27. Uluturhan E, Kontas A, Can E. Sediments concentrations of heavy metals in the Homa Lagoon (Eastern Agean Sea): Assessment of contamination and ecological risks. Marin Pollu 2011;62:1989-97.

28. Assi MA, Hezmee MNM, Haron AW, Sabri MYM, Rajion MA. The detrimental effects of lead on human and animal health. Vetera 2016;9:660-71.

29. A. Impact of different types of polluted irrigation water on soil fertility and wheat grain yield in clayey black soils of central India. Envi Monit Assess. 2014;186:2349-56.

30. Ministry of the Environment (2004). Soil , Ground Water and Sediment Standards for Use Under Part XV . 1 of the Environmental Protection Act 40.

31. Cavin O. Distribution of Heavy Metals in Water and Sediments of Lower River Nzoia. 2017;6:537-46.

32. Balentine B. Permissible limits for metals. 1995; 95:9-10..

33. Deciduous CA, Citrus N, Clover B, Tall O, Dallis R, Cotton W, Barley L, Rhodes B, Sar S, Sar M, Sar H, Heavy metals and metalloids. Australian and New Zealand Guidelines for Fresh and Marine Water Quality. 200;3:11-13.

34. Broun ER, Greist A, Tricot G, Hoffman R. Excessive zinc ingestion- A reversible cause of sideroblastic anemia and bone marrow depression", J of Ameri Medi Asso. 1990;264:1441-43.

35. Yamaguchi M, Takahashi K, Okada S. Zinc-induced hypocalcemia and bone resorption in rats", Toxico and Appl Pharmaco. 1983;67:224-228.

36. Rath, FW, Körtge R, Haase, P, Bismarck M, Effect of the oral administration of zinc on metastasis after intravenous application of benzpyrene induced rat sarcoma. Actahistochemica. 1990;39(Suppl):201-03.

37. U.S. Environmental Protection Agency Office of Water (4304T) Drinking Water Health Advisory for Manganese, Health and Ecological Criteria, Division Washington, DC 20460.

\section{Figures}




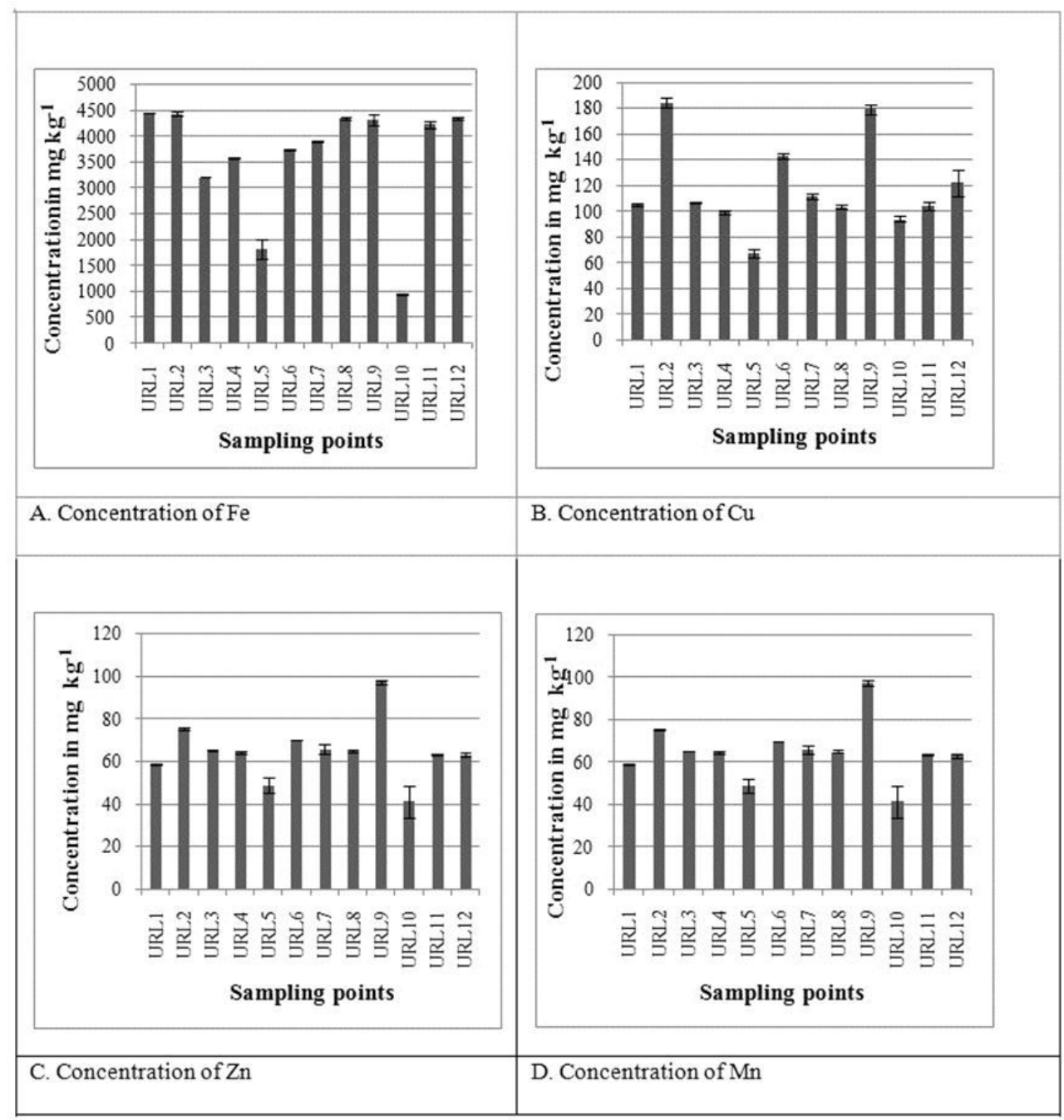

\section{Figure 1}

The concentration of heavy metals in sediment samples collected from Ujjani Reservoir (in mg kg-1) 


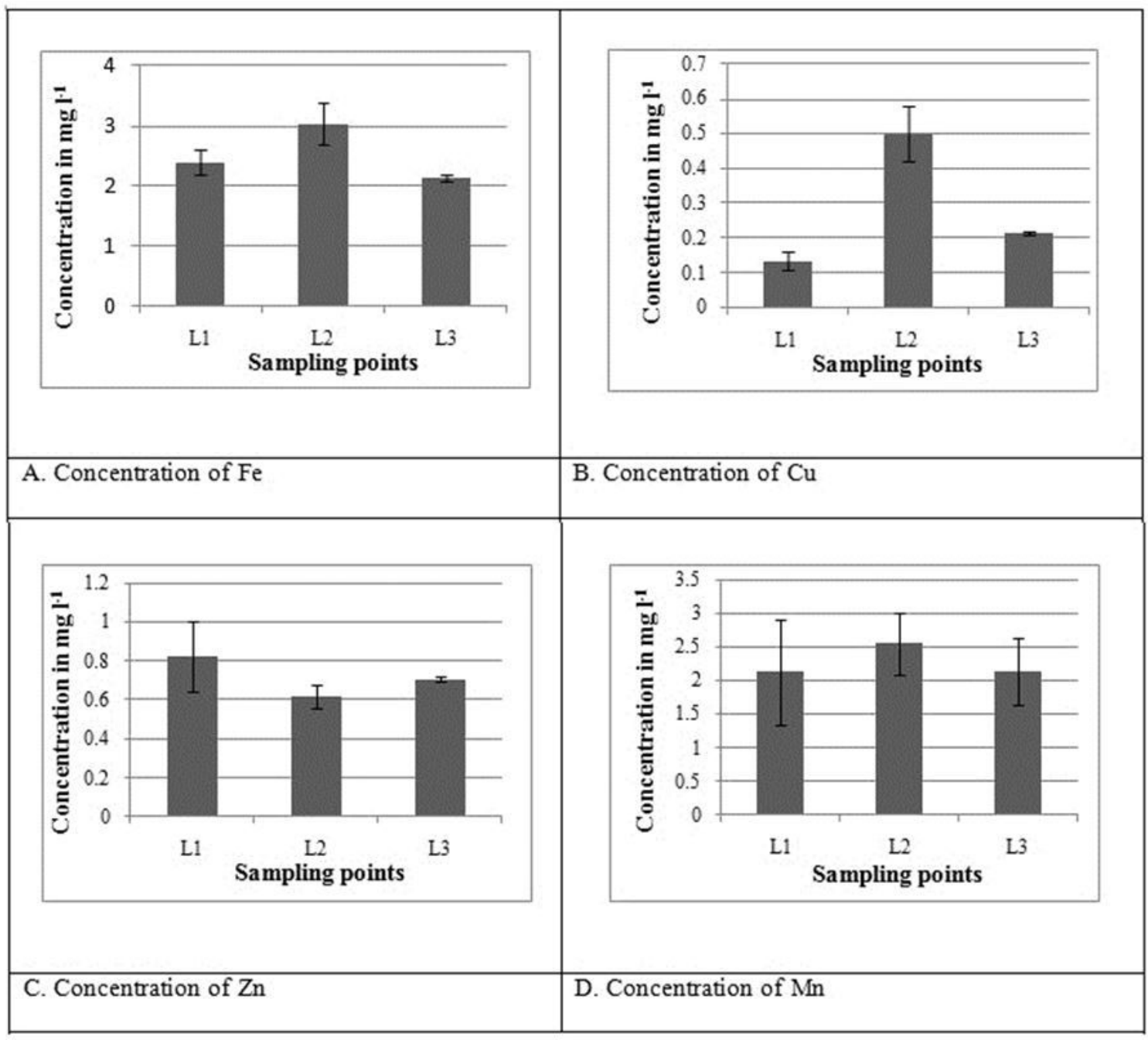

Figure 2

Concentrations of various heavy metals in surface water samples collected from Ujjani Reservoir. 